Volume 21 (2021) Issue 2

DOI: $10.2478 /$ foli-2021-0021 | 148-167

ISSN (print): 1730-4237 | ISSN (online): 1898-0198 www.wnus.edu.pl/fos

OPEN 2 ACCESS

\title{
TESTING THE VALIDITY OF THE LONG RUN NEUTRALITY OF MONEY IN NIGERIA
}

Ephraim Ugwu, MSc.

Department of Economics, Federal University, Oye-Ekiti, Nigeria

e-mail: ephraim.ugwu@fuoye.edu.ng

ORCID: 0000-0003-0522-3492

Christopher Ehinomen, Ph.D.

Department of Economics, Federal University, Oye-Ekiti, Nigeria

e-mail: christopher.ehinomen@fuoye.edu.ng

ORCID: 0000-0002-5757-8116

Philip Nwosa, Ph.D.

Department of Economics, Federal University, Oye-Ekiti, Nigeria

e-mail:philip.nwosa@fuoye.edu.ng

ORCID: 000-0001-6073-6659

Olubunmi Efuntade, MSc.

Department of Economics, Federal University, Oye -Ekiti, Nigeria e-mail: olubunmi.efuntade@fuoye.edu.ng

ORCID: 0000-0001-9935-026X

Received 19 May 2021, Accepted 22 October 2021

\begin{abstract}
Research background: There is no consensus among scholars on the interaction effect between money supply, price, and wages despite various studies conducted to that effect.

Purpose: This study investigates whether the neutrality of money assumption holds in the long run in Nigeria, using annual data from 1970 to 2018.

Research methodology: The study utilized the Johansen cointegration test and the Vector Error Correction (VECM) approach for estimation.

Results: The results from the Phillips curve model contradict the classical school of economics assumption that money is neutral in the long run. This implies that in the Nigerian economy, money is not neutral in the long run. The long run Fishers' effect model shows that the coefficient of LOG (CPI) exhibits a negative sign and is statistically significant at a $5 \%$ significant level, thus contradicting the hypothesis which
\end{abstract}


states that a one percent increase in consumer prices will lead to an increase in the rate of interest by one percent. The coefficient of nominal money supply indicates a negative sign and insignificant statistically on the interest rate. The Short-run estimated results showed that the coefficient of the error correction term ECM (-1) indicates a negative sign and is significant statistically in the Fishers' effect model. The result shows the actual and equilibrium values are corrected with adjustment speeds equal to $31 \%$ yearly.

Novelty: The study recommends that the Central Bank of Nigeria should ensure an effective implementation of monetary targeting measures in fine-tuning the economy and curbing inflationary pressures.

Keywords: Money neutrality, money supply, Phillips Curve, Fisher effect, cointegration, VECM

JEL classification: B22, C22, E58

\section{Introduction}

The view of monetary economists is that there is a certain neutral effect on the real variables as Governments inject liquidity into the economy. The implication is that changes in the money stock would affect nominal prices as well as wages, but the real variables like consumption, real wages, real interest rate, and output would be left unaffected (Bullard, 1999). The neutrality of money refers to the long-run implication of injecting liquidity into the economy, which implies that real variables in the economy do not change as the economic decision-making process is left unchanged, since decision-making in the economy is based on real factors (Bullard, 1999). The long-run neutrality of money typically refers to a specific, hypothetical experiment that is not normally observed directly in actual economies. The experiment is a one-time, permanent, unexpected change in the level of the money stock (Bullard,1999). If for instance, the money stock was five billion naira one day and had been five billion for a long time, then what would be the effect if the money stock changes to six billion naira and it remains for a long time?

Issues relating to money neutrality originated from the quantity theory of money which postulates that if innovations in the money supply in the economy were engineered exogenously by the monetary authorities, then the effect of such changes will be in proportionate to the price level changes, thereby leaving the real variables unchanged (Chuku, 2011). The long-run proposition of the quantity theory of money in recent time has resulted in what is called "longrun neutrality triplex". Firstly, the proposition that changes in money supply has no effect on the real variables in the long run; the second is the long-run Fisher effect, which postulates that changes in the inflationary level of the economy have no effect on the rate of interest in the long run. The third is that of the long-run Philips curve approach which states that inflationary 
changes in the economy, in the long run, have changed the level of unemployment (Chuku, 2011).

The quantity theory of money stated that there would be a rise in the price level in proportion to the increase in the quantity of the money stock, which affects real variables; however, after a period of transition, there is a return to the original values and it remains until further disturbances occur, implying the long-run neutrality of money (Bullard, 1999). According to the author, experimenting hypothetically, the new level of money stock should be maintained for a long period of time, thus allowing the transition effect to disperse. It is expected that changes in the money stock should be permanent theoretically. But in real-world economies, there is a high degree of persistence in most macroeconomic variables, thus making it difficult to differentiate between permanent and high persistence. Thus an increase of the money stock is offset by an equal rise in prices and wages (Bullard, 1999).

In Nigeria, the Central Bank of Nigeria $(\mathrm{CBN})$ has the sole responsibility of promoting price stability which is one the major objectives of monetary policy. This ensures that price stability is maintained in the economy. The CBN in a quest to fulfill its mandate had adopted different monetary policy frameworks, which includes exchange rate targeting starting from the introduction of the country's currency, the naira; and also monetary targeting, aimed at targeting the economy's growth in the monetary aggregates. The major features of the CBN monetary targeting includes the maintenance of a stable exchange rate and lower inflation (The CBN report, 2017). The $\mathrm{CBN}$ had adopted monetary policy as financial programming aimed at maintaining implicit inflation targeting and external reserve requirements in line with the real economic activity and money supply growth on which the economy maintains its absorptive capacity as well as derivable domestic credit (Adamgbe, 2006). The CBN report (2017) further noted that there had been a move in recent times to expand the mandate of the apex bank to include the maintenance of low unemployment, as a result of a continuous rise in unemployment level in the Nigerian economy.

Despite various studies conducted on the interaction effect between money supply, prices and wages, no consensus has been reached among scholars regarding both the theoretical and empirical aspects of this issue. Various Schools of thought, such as the Keynesians, Classicals, Monetarists, the New Classicals, and the Post-Keynesians, have provided different views on the interaction effect between the variables (Filho, 2015). The traditional Keynesian theory stated that product prices are determined as a mark-up over the cost of various inputs. This implies that product prices are affected by the changes in nominal wages. In this case, a wage becomes an exogenous variable that determines the inflationary level of the economy. On the contrary, the 
Classical school was of the view that that nominal wages will respond to changes in the price level, thus maintaining constant real wages. However, modern economic theory suggests that money supply determines both the price and the wage level (Filho, 2015).

Further, the Monetarists argued in favour of monetary neutrality and with the classical, assert that in the long run, wages do not determine the price level and that changes are as a result the changes in the money supply. They however support the view that short-run inflation is due to changes in wages. Thus, monetarists support the existence of a unidirectional causality existing from the money supply to the price level, while they support the view that there is no causal relationship between the price level and wages (Mishra, Verma, 2017). Contrary to the Monetarists' view, the Post-Keynesians argue in support of the endogeneity of money, that a change in prices or wages will lead to a change in the level of money supply (Nayan, Kadir, Abdullah, Ahmad, 2013).

Following the classical dichotomy, that change in the money stock affect only the nominal variables in the economy, thereby leaving the real variables unchanged, this study, therefore, tends to answer the two following questions: Does the move made by the Central Bank of Nigeria in controlling monetary aggregates point to the fact that money does not affect output in Nigeria? How do real variables react as a result of a change in money supply? If none of the real economic variables would change in response to the change in money supply, then the money is neutral. The overall objective of this study is to determine the effect of the broad money supply on the real variables in the long run in Nigeria and to ascertain whether the supply of money in Nigeria conforms to the neutrality effect of the Neo-Classical school on the real variables in the economy.

Studies conducted on the neutrality of money in Nigeria have found mixed results. For instance Anoruo (2005) found that the impact of monetary policy in Nigeria depends on whether it is anticipated or unanticipated. While Amassoma and Badmus (2020) in a study of long run money neutrality in Nigeria showed that the Philips curve result refutes monetary neutrality in Nigeria, while the fisher effect validates money neutrality in Nigeria. This study therefore tends to either validate or refute the theoretical propositions on the validity of the long run monetary neutrality in Nigeria by expanding the scope from 1970 to 2018 in order to observe the long run effect.

The paper is arranged as follows: section one is the literature review, and section two is focused on the methods adopted for empirical evaluation. Section three contains the results and section four is the conclusion 


\section{Literature review}

The literature on monetary neutrality includes a study by Hume (1752), Phillips (1958), Friedman (1968), and Phelps (1968). The arguments had focused on the influence of money in an economy. It is argued that the causes of both nominal and real fluctuations in an economy are a result of monetary shocks. The authors were of the view that as money supply increases it would lead to short-run increases in output and long-run increment in the price level. Phillips (1958) showed that there exists a direct relationship between the level of prices and the economy's real activity. A later study by Friedman (1968) and Phelps (1968) noted that the relationship is wholly a short-run phenomenon. Lucas (1972) explained that the controversies had centered on the role money plays in a business cycle. The author modeled the business cycle as a consequence of unanticipated fluctuations of money in an economy; while Kydland and Prescott (1982) viewed the business cycle as a consequence of an efficient response of the economy to a technological disturbance.

Further, Lucas (1972) on the hypothesis of agent rationality asserted money supply changes in an economy should not have a real effect under rational expectation and perfect foresight, as the changes are anticipated and discounted. When money supply changes are unanticipated in an economy, it affects the output. This indicates that economic agents do not have rational expectations nor perfect foresight (Lucas, 1972). However, studies by Baro and Rush (1980) and Mishkin (1983) concluded that anticipated money also affects output, while Boschen and Grossman (1982), noted that it is not clear that unanticipated components of the money supply change the economic real activity.

On the other hand, on the endogeneity of money supply, there is a consensus among the post-Keynesian economists, with individual views regarding the efficiency of the horizontal supply of the money curve. Howells (1995) asserted that the horizontal supply curve does not represent the stock of money supply. The horizontal money supply curve according to the author indicates a flow of money reserve during the market period. On the other hand, Lovoie (1996) argued that the horizontal supply of the money curve is part of the post-Keynesian views, which include financial innovation, theory of liquidity preference, non-accommodating Central Bank behaviour, increasing risk principle, and portfolio adjustment. The post-Keynesian theory views the supply of money as endogenous. The endogeneity of the money supply proposition overturns the neoclassical assumption that the money supply is controlled by the central bank, depending on factors outside the financial market. Thus they maintained that the money supply in terms of credit availability and its fluctuations are determined by the factors within the 
financial market. The post Keynesians maintained that the apex bank is incapable of controlling the economy's volume of money stock since money creation is demand determined (Lovoie, 1996).

In the theory of money supply endogeneity, there are three distinct views which include, the accommodationists, structuralists, and the liquidity preference views. The three views however agree that the supply of money is determined within the financial market from the demand side (Ahmad, Ahmed, 2006). The accommodationists were of the view that credit money is determined endogenously by credit-worthy customers. Though the Central bank as the issuer of fiat money determines the supply price of finance using its own discretion. The accommodationists consider the rate of interest to be determined exogenously by the apex bank. They assert that an increase in spending demands a huge working capital by firms or an increased money demand by households, leading to an increased loan demand from the banking industry. As loans are granted, it creates deposits; since deposits are considered as a means of payment, it is reproduced as the money supply in the economy increases (Ahmad, Ahmed, 2006).

The structuralists view on the endogeneity of money is that supply of money is an upward slope, stressing that banks can avoid apex banks restrains by creating innovation in the their services and in other financial instruments through the provision of liquid financial assets. This therefore results a horizontal money supply curve. The liquidity preference view however asserts that interest rate determines the decision to borrow or to hold increased deposits (Ahmad, Ahmed, 2006).

Issues relating to the neutrality of money supply in both the short and long run were addressed by Lucas (1996), highlighting the theoretical approaches that might reconcile the short-run effect of an increased supply of money with its long-run neutrality effect. The author adduced reasons that there should be a satisfactory explanation of the theory of the real effect of monetary policy. Among the reasons include, a study conducted by Friedman and Schwartz (1963), arguing that major recessions recorded in the United States between the periods from 1867 to 1960 were all followed by monetary policy contraction; this suggests that monetary policy errors resulted in business cycle downturns experienced during the periods. Lucas (1996) stated that the great depression of 1923 to1933 happened as a result of monetary policy contraction. Other studies cited by Lucas include Sargent (1986) who argued that reductions in the monetary expansion in the post-civil war US did not translate to any unusual large output reduction in the hyperinflationary post-First World War economies of Europe. The author noted that the monetary reductions were conducted in line with the monetary policy reforms that 
were embarked upon. However, as a credible reform measure was announced, there was an abrupt end of the hyperinflationary condition. This evidence supports the monetary neutrality propositions (Lucas, 1996).

Further, some empirical studies in this area were evaluated and among the authors include, Nasim and Sayyed (2021) on the evaluation of the long run neutrality of money and long run super neutrality for the industrial sector and the whole economy in Iran using the ARIMA framework developed. The empirical result shows that money neutrality is accepted in the Iranian economy. Also, Amassoma and Badmus (2020) on the reappraisal of the long-run money neutrality in Nigeria from 1981 to 2018 using the normalized cointegration and Vector error correction estimates. The study showed that the Philips curve result refutes monetary neutrality in Nigeria. The study also finds that the fisher effect validates money neutrality effectively in Nigeria. Bozkurt (2018) evaluated the neutrality of the money supply hypothesis and applies to Turkey and the Shanghai Cooperation Organization countries. Utilizing a panel data set from 2000 to 2016, the results reveal a causality relationship between output and money supply. Mishra and Verma (2017) evaluated money-price relationship in India from 1950 to 2016 applying the causality test procedure. The results provided evidence of a long-run relationship between money and general prices Nayan et al. (2013) evaluated the post-Keynesian theory of endogenous money for 177 countries utilizing a dynamic panel dataset from 1970 to 2011 . The findings support the post-Keynesian theory of endogenous money supply. Anoruo (2005) evaluates money neutrality in Nigeria from 1970-2002 using non-parametric integration and cointegration test procedures. The empirical result suggests that the impact of monetary policy in Nigeria depends on whether it is anticipated or unanticipated.

Studies conducted on the validity of the long run money neutrality have shown mixed results. For instance Amassoma and Badmus (2020) in a study of long run money neutrality in Nigeria showed that the Philips curve result refutes monetary neutrality in Nigeria, while the fisher effect validates money neutrality effectively in Nigeria. Anoruo (2005) on the other hand found that impact of monetary policy in Nigeria depends on whether it is anticipated or unanticipated. Bozkurt (2018) results reveal a causal relationship between output and money supply. Mishra and Verma (2017) find evidence of a long-run relationship between money and general prices. On the other hand, the results of Nayan et al (2013) support the post-Keynesian theory of endogenous money supply. This study therefore tends to either validate or refute the theoretical propositions on the validity of the long run monetary neutrality in Nigeria using annual data from 1970 to 2018 in order to observe the long run effect. 


\section{Research methodology}

This study utilized models based on the theories of monetary neutrality. The longrun Phillips curve and the Fishers effect theories are adopted. To ascertain if the monetary neutrality assumption holds in the Nigerian economy, the two theories will be evaluated. Thus the estimation outcome would determine if the a-priori expectation holds or not, hence it becomes the benchmark to evaluate the long-run neutrality of money in Nigeria. The Fishers' effect hypothesis states that as the inflationary level of the economy rises, the rate of interest would also rise. The monetary economists argued that the effect of monetary policy changes on the rate of interest is associated with the rate at which expectations adjust to new policy pronouncement. In the case of expansionary monetary policy measures, the expectation of the general public is that there will be a rise in inflation and also, the nominal interest rate will increase instead of decrease. This is in line with Fisher's (1930) proposition that as the lenders anticipate high demand for money, they will increase the interest rate and the borrowers in this case are willing to pay a higher interest rate. The Fishers' effect hypothesis is therefore stated as follows:

$$
R I R_{t}=I N T_{t}-I N F_{e}
$$

This implies that real interest rate (RIR) at time ( $\mathrm{t}$ ) equals nominal interest rate (INT) at time $(\mathrm{t})$, minus expected inflation $\left(\mathrm{INF}_{\mathrm{e}}\right)$. Thus the equation then becomes:

$$
I N T_{t}=f\left(I N F_{e}\right)
$$

There are other factors affecting the nominal rate of interest in the economy. As such, the study includes money supply in the equation. This helps in ascertaining its effect on the real variables and rate of interest (Ammassoma, Badmus, 2020). Thus the equation is specified as follows:

$$
I N T_{t}=f(C P I, M S)_{t}
$$

where:

$I N T$ - nominal rate of interest,

CPI - Consumer Price Index (proxy for inflation),

$M S$ - Broad Money Supply.

Transforming the equation into an econometrics form, the equation becomes:

$$
I N T_{t}=\beta_{0}+\beta_{1} C P I_{t}+\beta_{2} M S_{t}+\varepsilon_{t}
$$


where:

$$
\begin{aligned}
& \beta_{0}-\text { the intercept term, } \\
& \beta_{1} \text { - parameter estimate, } \\
& \varepsilon_{t}-\text { error term. }
\end{aligned}
$$

The variables are further transformed into logarithm, and the equation is stated as follows

$$
I N T_{t}=\alpha_{0}+\alpha_{1} L O G(C P I)_{t}+\alpha_{2} L O G(M S)_{t}+v_{t}
$$

\subsection{Estimation Procedures}

The stationarity property of the variables employed is analyzed. Most of the time series variables are prone to issues of stationarity (or random walk) problems. Thus to evaluate the stationarity properties of the variables under consideration, the Augmented Dickey-Fuller (ADF) test procedure is utilized. The equation of the ADF test is specified as follows:

$$
\Delta \mu_{t}=\beta \mu_{t-1}+\sum_{i=1}^{k} \Delta \mu_{t-1}+\varepsilon_{t}
$$

Also, the cointegration tests procedure is conducted by utilizing Johansen (1988), and Johansen, and Jusellius (1990) multivariate approach. Finally, the study conducted a diagnostic test to evaluate the robustness of the parameter estimates of the model. The annual time series data covering the period's from1970-2018 are utilized. The data used were obtained from the Central Bank of Nigerian (CBN) Statistical Bulletin 2018 and the World Bank Development Indicators ${ }_{1} 2018$.

\subsection{The Vector Error Correction (VECM) Model}

As all the variables in the model are not stationary at level differences, the VECM approach is therefore adopted for the result evaluation. The equation for the VECM approach is stated as follows:

$$
\Delta Y_{t}=\Gamma_{1} \Delta Y_{t-1}+\Gamma_{2} \Delta Y_{t-2}+\ldots \Gamma_{p-1} \Delta Y_{t-p+1}+\Phi Y_{t-1}+\varepsilon_{t}, t=1, \ldots, T
$$

where:

$$
\Gamma_{i}=-\left(1-\Pi_{1}-\ldots-\Pi_{i}\right)(i=1, \ldots, p-1), \Phi_{i}=-\left(1-\Pi_{1}-\ldots-\Pi_{p}\right), \Phi_{i}=\alpha \beta^{\prime}
$$

where: $\alpha$ represent an adjustment to disequilibrium speed and the matrix of the long-run coefficient is represented by $\beta$. While $\beta^{\prime} Y_{t-1}$ is a single equation model error correction term and $\beta^{\prime} Y_{t-1}$ is a multivariate model which contains $(n-1)$ vectors. 
The VECM approach possesses several advantages which include that it determines longrun and short-run causalities if the coefficient is statistically significant and is different from zero, indicating that there exists a long-run causality. A VECM is an aspect of the VAR model used for variables that are cointegrated.

This study utilized two models based on the money neutrality assumptions. The fisher effect hypothesis and the long run Phillips curve approach. Hence, the aim is to ascertain if the estimated results goes in line with theoretical expectations or not. The first model is the Fisher effect hypothesis which states that when there is a rise in inflation expectation, there will also be a rise in the nominal rate of interest on one to one basis. Therefore, the fisher effect approach is stated as follows:

$$
X_{t}=(I N T, L O G(C P I), L O G(M S))
$$

where $X_{t}$ is a vector of three endogenous variables.

Therefore, with a simple VAR model with $\mathrm{k}$ lags, the equation is expressed as follows:

$$
X_{t}=\beta_{1} X_{t-1}+\beta_{2} X_{t-2}+\ldots+\beta_{k} X_{t-k}+\mu_{t}
$$

where: $X_{t}=(I N T, L O G(C P I), L O G(M S)) ; \beta_{i}=3 \times 3$ matrix of parameters $i=1,2, \ldots, k$; $\mu_{t}=3 \times 1$ vector of multivariate normal random variables with a zero mean and variancecovariance matrix $\sum$.

In its simplest form, a VECM model could be stated as follows:

$$
\Delta X_{t}=\Pi X_{t-k}+\Omega_{1} \Delta X_{t-1}+\Omega_{2} \Delta X_{t-2}+\ldots+\Omega_{k-1} X_{t-(k-1)}+\mu_{t}
$$

where: $\Pi=\left(\sum_{i=1}{ }^{k} \beta_{i}\right)-I_{g}, \Omega=\left(\sum_{j=1}{ }^{k} \beta_{i}\right), k=3$ (for three variables VECM).

The second approach is the Philips curve which states that in the long run, money supply does not affect the real variables but rather affects the level of prices in the economy as a result of changes in the supply of money. In order to evaluate this assumption, the study utilized the Real Gross Domestic Product (RGDP) stated as a function of money supply in the economy as follows:

$$
R G D P_{t}=f(M S)_{t}
$$

where RGDP - the Real Gross Domestic Product. 
Stating the equation in an econometrics form becomes:

$$
R G D P_{t}=\alpha_{0}+\alpha_{1} M S_{t}+v_{t}
$$

where:

$\alpha_{0}$ - intercept term,

$\alpha_{1}$ - parameter estimate,

$v_{t}-$ error term.

Equally, the equation is transformed into logarithm as follows:

$$
L O G(R G D P)_{t}=\lambda_{0}+\lambda_{1} L O G(M S)_{t}+\mu_{t}
$$

In order to estimate the short run relationship between the RGDP and nominal money supply, a bivariate VECM is therefore specified as follows:

$$
\begin{aligned}
& \Delta y_{1 t}=c+\sum_{t=1}^{p} \pi_{11}^{i} \Delta y_{1 t-1}+\sum_{t=1}^{p} \pi_{12}{ }^{j} \Delta y_{2 t-j}+\phi_{1} E C M_{1 t-1}+\varepsilon_{1 t} \\
& \Delta y_{2 t}=c+\sum_{t=1}^{p} \pi_{21}^{i} \Delta y_{1 t-1}+\sum_{t=1}^{p} \pi_{22}{ }^{j} \Delta y_{2 t-j}+\phi_{2} E C M_{2 t-1}+\varepsilon_{2 t}
\end{aligned}
$$

where:

$c$ - intercept for both equations,

$\Delta y_{1 t}$ represent $\Delta L O G(G D P)_{t}$ and $\Delta y_{2 t}$ represent $\Delta L O G(M S)_{t}$,

$\varepsilon_{1 t}, \varepsilon_{2 t}-$ error terms.

\section{Data/results analysis}

In this section, an evaluation of the generated results was conducted accordingly. Figure 1 below shows the trend of the real GDP (log_rgdp) and the nominal money supply (Log_MS) in the Nigerian economy from 1970 to 2018 . The result for the RGDP growth indicates that there was instant growth of the RGDP from 1970, but it declined in 1980. It took an upward swing and continued to fluctuate up to 2006. However, from the figure, it could be noted that there was an upward trend of the RGDP from 2007 to 2018 in the economy. This could be attributed to an increased in the prices of crude oil during the Gulf war, and a return to democratic rule in Nigeria in 1999. The nominal money equally indicated an upward trend from 1970 to 2000. However, from 2003 to 2006, the money supply growth recorded a downward trend. The money supply took an upward swing from 2007 and had maintained an upward trend up to 2018. 
The decline in the nominal money supply growth could be attributed to the decline in the GDP growth in 2005 and 2006 in the Nigerian economy.

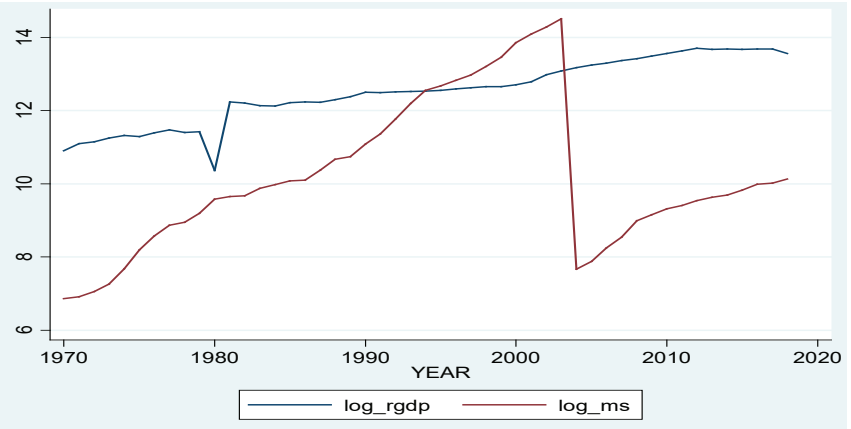

Figure 1. The trend of the real GDP and the nominal money supply from 1970 to 2018 Source: authors' computation from STATA 11 results.

Figure 2 shows the trend analysis of the nominal interest rate in the Nigerian economy from (1970-2018). The result indicates that the interest rate recorded a constant growth from 1970 to 1978 in the economy. The figure showed that from 1979 to 1995 there was an upward trend in the rise of the country's rate of interest. However, there was a decline in the interest rate growth from 1996 to 2000 and it continued on a downward trend till 2010. The interest rate growth took an upward trend from 2011 and continued on upward and downward trends till 2018. The trend analysis of the consumer prices index (log_cpi) showed that from 1970 it maintained an upward trend and continued on upwards to 2018. This could be attributed to high the inflationary level the Nigerian economy had been in since the currency (naira) was devalued during the structural adjustment programme.

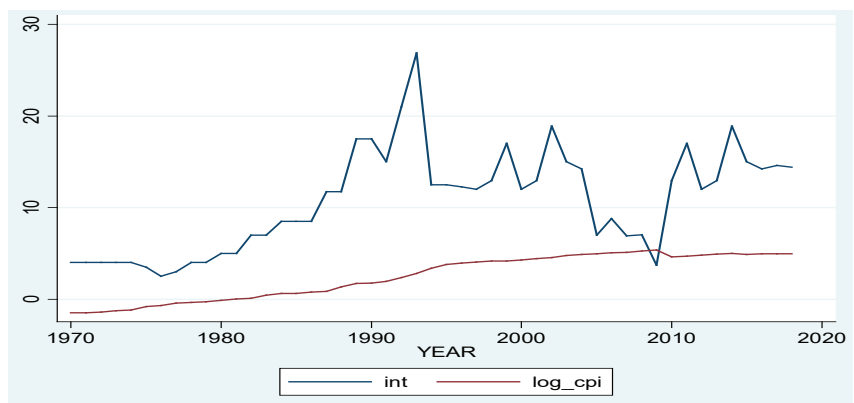

Figure 2. The trend of the nominal interest rate and the CPI from 1970 to 2018 Source: authors' computation from the STATA 11 results. 
From Table 1, the descriptive statistics of the variables under consideration indicate a positive mean values, for the variables, RGDP, CPI, MS, and INT, with 49 observations. The highest standard deviation is recorded by MS, while the least standard deviation is recorded by INT. The skewness statistics show that four of the variables are positively skewed

Table 1. The Descriptive statistics of the variables

\begin{tabular}{|l|c|r|r|c|}
\hline \multicolumn{1}{|c|}{ Variable } & Observation & \multicolumn{1}{c|}{ mean } & Standard Deviation & Skewness \\
\hline RGDP & 49 & $376,586.40000$ & $279,731.000000$ & 0.674079 \\
\hline CPI & 49 & 59.62214 & 65.517550 & 0.638954 \\
\hline MS & 49 & $194,696.40000$ & $428,429.800000$ & 2.809244 \\
\hline INT & 49 & 10.35469 & 5.665608 & 0.541915 \\
\hline
\end{tabular}

Source: authors' computation from Eviews 9 results.

The study conducted a diagnostic test using the VEC Residual Serial Correlation LM test procedure and is presented in Table 2: from the result, the null hypothesis of no serial correlation is accepted, thus the conclusion is that there is no serial correlation among the variables under consideration.

Table 2. The diagnostic tests result

\begin{tabular}{|c|c|c|}
\hline \multicolumn{3}{|c|}{ VEC Residual Serial Correlation LM Tests } \\
\hline \multicolumn{2}{|c|}{ Null Hypothesis: no serial correlation at lag order h } \\
\hline lags & LM-Stat & 0.9213 \\
\hline 1 & 8.801874 & \\
\hline Probs from chi-square with 16 df
\end{tabular}

Source: authors' computation from Eviews 9 results.

Table 3. The stationarity test results

\begin{tabular}{|l|c|c|c|c|c|c|}
\hline \multicolumn{7}{|c|}{ The Augmented Dickey Fuller Test (ADF) procedure } \\
\hline variable & level difference & prob. & $\begin{array}{c}\text { order } \\
\text { of integration }\end{array}$ & first difference & prob. & $\begin{array}{c}\text { order } \\
\text { of integration }\end{array}$ \\
\hline RGDP & -2.006442 & 0.2832 & & $-6.098353^{* *}$ & 0.0000 & I(1) \\
\hline MS & -2.576964 & 0.1047 & & $-7.324400 * *$ & 0.0000 & I(1) \\
\hline CPI & -0.824723 & 0.8029 & & $-7.442068^{* *}$ & 0.0000 & $\mathrm{I}(1)$ \\
\hline INT & -2.543955 & 0.1118 & & $-8.557356^{* *}$ & 0.0000 & $\mathrm{I}(1)$ \\
\hline
\end{tabular}

$*, * *$ and $* * *$ indicate $1 \%, 5 \%$ and $10 \%$ significant levels respectively.

Source: authors' computation from Eviews 9 results. 
In order to evaluate the time-series properties of the variables, the stationarity test procedure was conducted using the Augmented Dickey-Fuller Test (ADF) procedure, and the test results presented in Table 3. The results generated show that none of the variables is stationary at the level. However, at first difference, I(1), all the variables are stationary at 5\% significant levels. A cointegration test procedure is therefore conducted using the Johansen test procedure.

In order to conduct the cointegration test, it is important to determine the lag order of the cointegration test. From the lag order criterion results presented in Table 4, the study adopts a lag order of 1 based on the Akaike information criterion (AIC), Schwarz information criterion (SC), and Hannan-Quinn information criterion (HQ) respectively. The results are supported by the Final prediction error (FPE). Therefore, the optimal lag length for this test procedure is lag 1.

Table 4. the optimal lag length selection

\begin{tabular}{|c|c|c|c|c|c|c|}
\hline Lag & LogL & LR & FPE & AIC & SC & HQ \\
\hline 1 & -38.15392 & NA & $0.024356^{*}$ & $1.960647^{*}$ & $2.124480^{*}$ & $2.021064^{*}$ \\
\hline 2 & -36.17559 & 3.588593 & 0.026783 & 2.054679 & 2.382344 & 2.175511 \\
\hline 3 & -35.68460 & 0.844961 & 0.031613 & 2.217888 & 2.709386 & 2.399138 \\
\hline 4 & -35.11517 & 0.926981 & 0.037271 & 2.377450 & 3.032780 & 2.619115 \\
\hline 5 & -34.41437 & 1.075642 & 0.043826 & 2.530901 & 3.350064 & 2.832983 \\
\hline 6 & -34.09561 & 0.459606 & 0.052696 & 2.702122 & 3.685117 & 3.064620 \\
\hline
\end{tabular}

* Indicates lag order selected by the criterion.

Source: authors' computation from Eviews 9 results.

Based on the results, we select lag order one using both the AIC, SC, and HQ criteria. Utilizing the VAR specification is important, in that it helps in computation for both impulse response function and variance decomposition, such that it allows for functions of the dependent variable to one standard deviation shock in another variable in the system (Rad, 2014). Furthermore, the cointegration test was conducted both for the two equations. From the result presented in table 5, the Fishers effect model results indicate one cointegrating equations in the Trace test and Maximum Eigenvalue test procedures respectively. While for the Phillips curve model, the result shows two cointegrating equations in both the Trace test and Maximum Eigenvalue test approaches respectively. This implies that there exists a long-run relationship between the variables under consideration. 
Table 5. The cointegration test results

\begin{tabular}{|c|c|c|c|c|c|c|c|}
\hline \multicolumn{7}{|c|}{ Trace Statistics } & \multicolumn{5}{c|}{ Maximum Eigenvalue test } \\
\hline null & alternative & statistics & $\begin{array}{c}0.05 \\
\text { critical value }\end{array}$ & null & alternative & statistics & $\begin{array}{c}0.05 \\
\text { critical value }\end{array}$ \\
\hline \multicolumn{7}{|c|}{ The Phillip curve } \\
\hline $\mathrm{r}=0$ & $\mathrm{r} \geq 1$ & 42.332030 & 15.494710 & $\mathrm{r}=0$ & $\mathrm{r}=1$ & 37.153590 & 14.264600 \\
\hline $\mathrm{r} \leq 1$ & $\mathrm{r} \geq 2$ & 5.178440 & 3.841466 & $\mathrm{r} \leq 1$ & $\mathrm{r}=2$ & 5.178440 & 3.841466 \\
\hline \multicolumn{7}{|c|}{ The Fishers effect } \\
\hline $\mathrm{r}=0$ & $\mathrm{r} \geq 1$ & 41.241650 & 29.797070 & $\mathrm{r}=0$ & $\mathrm{r}=1$ & 25.919010 & 21.131620 \\
\hline $\mathrm{r} \leq 1$ & $\mathrm{r} \geq 2$ & 15.322640 & 15.494710 & $\mathrm{r} \leq 1$ & $\mathrm{r}=2$ & 10.946630 & 14.264600 \\
\hline $\mathrm{r} \leq 2$ & $\mathrm{r} \geq 3$ & 4.376013 & 3.841466 & $\mathrm{r} \leq 2$ & $\mathrm{r}=3$ & 4.376013 & 3.841466 \\
\hline
\end{tabular}

Source: authors' computation from Eviews 9 results.

In order to evaluate further based on the two cointegrating equations for the Phillip curve results, the study estimated a normalized long-run regression, and the results are presented in Table 6.

Table 6. The long run estimated result

\begin{tabular}{|c|c|}
\hline \multicolumn{2}{|c|}{ Phillips curve approach } \\
\hline LOG(RGDP) & LOG(MS) \\
\hline 1.000000 & 1.743347 \\
\hline & $(0.85528)$ \\
\hline C & {$[2.03833]$} \\
\hline Log likelihood $=-70.07773$ & -30.56151 \\
\hline
\end{tabular}

Note: Standard errors in ( ) and t-statistics in [ ].

Source: authors' computation from Eviews 9 results.

From the results above, the relationship between nominal money supply and the real economic growth show that the coefficient of the variable LOG (MS) indicates a positive sign and is statistically significant at a $5 \%$ level. This result shows that a one percent increase in the supply of money in the economy leads to a $1.7 \%$ increase in the RGDP. The outcome of the result contradicts the classical school of economics assumption that money is neutral in the long run. This implies that in the Nigerian economy, money is not neutral in the long run. The result conforms to the findings of Puah, Habibullah, and Abu (2008) in a study of the South East Asia economies that there is a positive long-run impact of money supply on RGDP in Indonesia, Taiwan, and Thailand. Thus indicating that long-run neutrality of money does not hold in these 
three countries. Similarly, the result is in line with the findings of Bozkurt (2018) who found that the hypothesis of monetary neutrality does not apply to Turkey and the Shanghai Cooperation Organization countries.

For the Fishers' effect model, the VECM results as presented below in Table 7, show both the long-run and short run estimated results. The long run estimated results indicate that LOG (CPI) exhibits a negative sign and is statistically significant on the interest rate. This implies that one percent increase in the rate of inflation reduce the rate of interest by $1.8 \%$. The result supports the theoretical postulation which states that as the inflation rate increases, it reduces the real rate of interest as a result of a change in the time value of money. However, the result contradicts the Fishers' effect hypothesis which states that a one percent increase in consumer prices will lead to an increase in the rate of interest by one percent. Hence showing that in the long run, money is not neutral in the Nigerian economy.

Table 7. The VECM results (the Fishers effect model)

\begin{tabular}{|c|c|c|c|c|}
\hline \multicolumn{5}{|c|}{ PANEL A - Long Run Estimate } \\
\hline $\begin{array}{c}\text { dependent } \\
\text { variable }\end{array}$ & regressors & estimated co-efficient & standard error & t-Statistics \\
\hline \multirow{3}{*}{$\operatorname{INT}(-1)$} & $\operatorname{LOG}(\mathrm{CPI}(-1))$ & -1.801530 & 0.41200 & -4.37261 \\
\hline & $\operatorname{LOG}(\mathrm{MS}(-1))$ & -0.233679 & 0.48881 & -0.47806 \\
\hline & $\mathrm{C}$ & -3.477582 & & \\
\hline \multirow{5}{*}{ The short run estimate } & $\mathrm{D}(\mathrm{INT}(-1))$ & -0.040526 & 0.13690 & -0.24659 \\
\hline & $\mathrm{D}(\mathrm{LOG}(\mathrm{CPI}(-1)))$ & 3.682737 & 3.18307 & 1.15698 \\
\hline & $\mathrm{D}(\operatorname{LOG}(\mathrm{MS}(-1)))$ & 0.936939 & 0.51300 & 1.82638 \\
\hline & $\operatorname{ECM}(-1)$ & -0.316489 & 0.13690 & -2.31176 \\
\hline & $\mathrm{C}$ & -0.338818 & 0.68985 & -0.49115 \\
\hline R-squared $=0.225891$ & Adj. R-squared $=0.152167$ & $\mathrm{AIC}=5.494857$ & \multicolumn{2}{|c|}{ F-statistic $=3.063989$} \\
\hline
\end{tabular}

Source: Authors' computation from Eviews 9 results.

Equally, the money supply coefficient indicates a negative sign and is insignificant statistically on the interest rate. This result is in line with findings by Yunana and Amba (2016) that there exists a negative relationship between money supply, exchange rate, and interest rate in Nigeria. Moreover, the result is in line with the classical and New Classical theorists' view that money supply has no implication on the rate of interest. Hence, supporting the assumption of the quantity theory of money that there is a dichotomy between monetary policy and real sectors (Anyanwu, 1993; Mishkin, 1989). 
The short-run estimated result in Table 7, show that the coefficient of the error correction term $\operatorname{ECM}(-1)$ indicates a negative sign and is significant statistically. The result shows that the variables under consideration are cointegrated in the long run. Thus the actual equilibrium values are corrected with an adjustment speed equal to $31 \%$ yearly. The coefficient of the lagged value of interest rate shows a negative sign and insignificant statistically. The coefficient of the LOG(CPI(-1)) shows a positive sign and is insignificant in the short run. However, the coefficient of money supply $\operatorname{LOG}(\operatorname{MS}(-1))$ indicates a positive sign and is significant statistically. It shows that a one percent increase in the money supply leads to a $93 \%$ increase in the rate of interest in the short run. This result disputed the classical dichotomy that money supply has no implication on the rate of interest. Statistically, the coefficient of determination $R^{2}$ indicates a value of 0.225891 , and the adjusted $R^{2}$ value of $=0.152167$ respectively. This implies that $15 \%$ of the variations in the dependent variable can be explained by the independent variables in the model.

\section{Conclusions}

The views of the monetary economists are that in the long-run, money supply is neutral; and the classical economists, assert that wages do not determine the level of prices, and that changes are a result of the changes in the money supply. Thus, the classical dichotomy asserts that changes in the money stock affect only the nominal variables in the economy, leaving the real variables unchanged. The post-Keynesians, however, supports the endogeneity of money, implying that as price level or wages change, it will result in a change in the level of money supply in the economy. It is on this premise that this study is conducted to ascertain the validity of the long-run neutrality of money supply in Nigeria.

The estimated results revealed that all the variables are stationary at the first difference in both the Fisher effect and the Phillips curve models. The cointegration test results showed that the Fishers effect model indicates one cointegrating equations, while the Phillips curve model showed two cointegrating equations in both the Trace test and Maximum Eigenvalue test procedures. The study estimated a normalized long-run regression following the Phillips curve approach and from the result, the coefficient of the independent variable LOG(MS) indicates a positive sign and is statistically significant at a 5\% level. This result shows that a one percent increase in the supply of money in the economy leads to a $1.7 \%$ increase in the RGDP. The outcome of the result contradicts the classical school of economics assumption that 
money is neutral in the long run. This implies that in the Nigerian economy that money is not neutral in the long run.

However, the Fishers' effect model results in using a VECM procedure, and shows that LOG (CPI) exhibits a negative sign and is statistically significant on the interest rate. However, the result contradicts the Fishers' effect hypothesis which states that a one percent increase in consumer prices will lead to an increase in the rate of interest by one percent. Furthermore, the Short-run estimated results showed that the coefficient of the error correction term ECM $(-1)$ indicates a negative sign and is significant statistically in the Fishers' effect model. The result shows that the actual and equilibrium values are corrected with an adjustment speed equal to $31 \%$ yearly. The coefficient of the lagged value of interest rate shows a positive sign and is insignificant statistically. Also, the coefficient of the LOG(CPI) shows a positive sign and is statistically insignificant in the short run.

The study recommends that the Central Bank of Nigeria should ensure an effective implementation of monetary targeting measures in fine-tuning the economy and thus curbing inflationary pressures. The study further recommends that there should be coordination between the fiscal and monetary authorities in order to achieve the macroeconomic objectives of the country.

\section{References}

Adamgbe, E.T. (2006). Exchange Rate Management Under the Wholesale DAS in Nigeria: Policy Implications. West African Journal of Monetary and Economic Integration, 6 (1).

Ahmad, N., Ahmed, F. (2006). The Long-run and Short-run Indigeneity of Money Supply in Pakistan: An Empirical Investigation. SBP-Research Bulletin, 2 (1).

Amassoma, D., Badmus, A. (2020). Re-Appraisal of the Validity of Long-Run Money Neutrality: An Evidence from Nigeria. Acta Universitatis Danubius, 16 (3), 53-73.

Anoruo, E. (2005). Testing Neutrality of Money for Nigeria: A Nonparametric Cointegration Approach. The ICFAI Journal of Monetary Economics, 3 (4), 16-25.

Anyanwu, J.C. (1993). Monetary Economics, Theory and Institution. Onitsha: Hybrid Publisher Limited.

Barro, R.J., Rush, M. (1980). Unanticipated Money and Economic Activity. In: S. Fischer (ed.), Rational Expectations and Economic Policy (pp. 23-48). Chicago: University of Chicago and NBER. 
Boschen, H., Grosman, H. (1982). Test of Equilibrium Macroeconomic using Contemporaneous Monetary Data. Journal of Monetary Economics, 10, 309-333.

Bozkurt, E. (2018). The Hypothesis of Neutrality of Money: Panel Data Analysis. Journal of Yasar University, 13 (52), 322-327.

Bullard, J.B. (1999). Testing long-run monetary neutrality propositions: Lessons from the recent research. Federal Reserve Bank of St. Louis Review, 81, 57-77.

Central Bank of Nigeria annual report (2017). Monetary policy implementation. Retrieved from: https://www.cbn.gov.ng.

Chuku, A.C. (2011). Testing Long-Run Neutrality Propositions in a Developing Economy: The Case of Nigeria Article. Journal of Economic Research (JER), 16, 291-308.

Filho, F.F. (2015). Keynesians, monetarists, new classical and new Keynesians: A post Keynesian critique. Análise Econômica Ano, 14 (96), 63-75. Retrieved from: https://www.researchgate.net/publication/267924343.

Fisher, I. (1930). The Theory of Interest. New York: Macmillan.

Friedman, M. (1968). The Role of Monetary Policy. American Economic Review, 58 (1), 1-17.

Friedman, M., Schwartz, A. (1963). A Monetary History of the United States, 1867-1960. Princeton University Press.

Johansen, S. (1988). Statistical Analysis of Cointegration Vectors. Journal of Economic Dynamics and Control, 12 (2/3), 231-254.

Johansen, S., Jusellius, K. (1990). Maximum Likelihood Estimation and Inference on Cointegration - with Applications to the Demand for Money. Oxford Bulletin of Economics and Statistics, 52 (2), 169-210.

Hume, D. (1752). Political Discourses. In: E. Rotwein (ed.), David Hume: Writings on Economics. London, Nelson, 1955.

Howells, P.G.A. (1995). Is There a Horizontal Money Supply Curve? Cyprus Journal of Economics, 8 (1), 41-63.

Kydland, F.E., Prescott, (1982). Time to Build and Aggregate Fluctuation. Econometrica, November (50), 1345-1370.

Lavoie, M. (1996). Monetary Policy in an Economy with Endogenous Credit Money. In: E. Nell, G. Deleplace (eds.), Money in Motion. London: Macmillan.

Lucas, R.E. Jr. (1996). Nobel lecture: monetary neutrality. Journal of Political Economy, 104, 661-682.

Lucas, R.J. (1972). Econometric Testing of the Natural Rate Hypothesis. In the Econometrics of Price Determination, Board of Governors of the Federal Reserve System.

Mishkin, F.S. (1989). The Economics of Money, Banking and Financial Markets. Second Edition, Scot. Boston: Foresman and Company. 
Mishkin, F. (1983). A Rational Expectations Approach to Macroecono-Metrics. Chicago: University of Chicago Press and NBER.

Mishra, P.K., Verma, J. (2017). Empirical evidence on money-price relationship in India: Cointegration and causality approach. International journal of economic research, 14 (4).

Nasim, I., Sayyed, A.J. (2021). Testing the long-run neutrality and super neutrality of money in a developing country: Evidence from Iran. Elsevier method, X(8). Retrieved from: www. elsevier.com/locate/mex.

Nayan, S., Kadir, N., Abdullah, M.S., Ahmad, M. (2013). Post Keynesian Endogeneity of Money Supply: Panel Evidence. Procedia Economics and Finance, 7, 48-54. DOI: 10.1016/ S2212-5671(13)00217-7. Retrieved from: www.sciencedirect.com.

Phillips, A.W. (1958). The Relation between Unemployment and the Rate of Change of Money Wages in the United Kingdom. Economica, 25, 283-299.

Puah, C., Habibullah, M.S., Abu, M.S. (2008). On the Long-Run Monetary Neutrality: Evidence from the SEACEN Countries. Munich Personal RePEc Archive MPRA Paper No. 31762. Retrieved from: https://mpra.ub.uni-muenchen.de/31762.

Rad, S.A. (2014). The relationship between corporate governance practices and cost of capital in large listed companies of New Zealand and Singapore. Doctor of philosophy (Ph.D.) Doctoral, The University of Waikato, Hamilton. Retrieved from: https://hdl.handle. net/10289/8656.

Sargent, T.J. (1986). The End of Four Big Inflations, in Rational Expectations and Inflation. Harper and Row.

Sulku, S.N. (2011). Testing the long-run neutrality of money in developing county, evidence from turkey. Faculty of Economics, Gazi University, Turkey. Journal of Applied Economics and Business Research, 1 (2), 65-74.

Tawadros, G.B. (2007). Testing for Long run Money Neutrality in the Middle East. Journal of Economic Studies, 34 (1), 13-28.

Yunana, T.W., Amba, D.A. (2016). The Implications of Money Supply on Interest Rate in Nigeria. American Journal of Business and Society, 1 (4), 189-194. Retrieved from: http:// www.aiscience.org/journal/ajbs.

\section{Citation}

Ugwu, E., Ehinomen, C., Nwosa, P., Efuntade, O. (2021). Testing the Validity of the Long Run Neutrality of Money in Nigeria. Folia Oeconomica Stetinensia, 21 (2), 148-167. DOI: 10.2478/ foli-2021-0021. 
